\title{
The Use of Governance and Mediation for Disaster Prevention and Environmental Risk Management
}

\author{
Gabriela Soldano Garcez<gabrielasoldano@unisantos.br> \\ Renata Soares Bonavides <renata.bonavides@unisantos.br> \\ SANTOS, São Paulo, Brasil
}

\section{Abstract}

This essay aims to demonstrate the cleary interconnection of the themes of economic development and environmental protection. Such connection is present especially when analyzing the need for the implementation of compliance mechanisms by the business sector, such as how to obtain the Sustainable Development Goals (SDGs), of the 2030 Agenda, formulated by the United Nations (UN), mainly with regard to SDG 17. Because, how this essay concludes, through collective participation mechanisms, it is possible to reconcile interests between all the actors involved in business processes, implemented by socio-environmental mediation in the search for the most appropriate and, currently, most sustainable solution.

Keywords:

Mediation; Governance; Risk management; Compliance; 2030 Agenda.

\section{Introduction}

Development cannot be understood (nor measured) only from an economic perspective. In a contemporary view (guided by the needs of today's complex and plural society), it should include the social and environmental dimensions. This implies that it is essential to maintain adequate environmental levels for human life for present and future generations.

The Brazilian Federal Constitution of 1988 follows this same line, by imposing the defense and protection of the environment on both the Public Power and the community, in a combination of collective efforts to maintain the environmental quality and the dignity of the human person. Therefore, it is necessary to seek a peaceful coexistence between elements of environmental protection, social resources and economic development. 
In this context, and in accordance with a socio-environmental model of State (which tries to direct economic activity in order to become more environmentally responsible), the instruments implemented by the business sector called environmental compliance gains prominence, as an instrument that allows the political and public management of the company combined with environmental protection, adding value to the sector in question through mechanisms of transparency, accountability and codes of conduct, in a real stimulus to risk management and prevention of environmental disasters.

This compliance instrument can be applied in practice through the pillars of governance and socioenvironmental mediation, in an attempt to allow, at the same time, the participation of everyone involved and interested in the discussions of adequate and sustainable environmental management.

In this line of reasoning, this article aims, at first, through a critical-deductive analysis carried out by a bibliographic reference survey on the main topics of this theme, to analyze the socio-environmental responsibility of companies for maintaining environmental quality levels, taking into account in view of the current experienced Risk Society. Then, it discusses how the implementation of instruments provided for compliance can contribute to the achievement of the SDGs of 2030 Agenda, especially with regard to SDG 17 (which deals with partnerships for sustainable development).

Finally, it correlates compliance with governance and socio-environmental mediation, considering that, for its adequate use, it is necessary to allow the broad participation of all actors involved in the theme (such as, for example, investors, partners, shareholders, banks, employees, consumers, among others, through governance) in the search for joint solutions, based on consensus, that serve the interests of all (through mediation).

As a successful example of this correlation, this article mentions the online platform "SDG Action Manager", created by B.Lab and the United Nations Global Compact, which does, for free and confidentially, a risk analysis of the actions of companies for its proper management. 


\section{Social and Environmental Responsibility of Companies}

Currently, due to a plural and complex society, which also can be considered a Risk Society ${ }^{1}$, companies must guide its socioeconomic decision-making according to environmental issues, bearing in mind the need to implement standards aimed at sustainability, because the effects of globalization mark the emergence of a world in which the risks produced by human activity that cannot be immediately perceived, measured and understood ${ }^{2}$.

For this reason, business decisions are so important, because it can cause innumerable reflexes internal and/or external impacts (which even go beyond generations, in a true "boomerang" effect ${ }^{3}$ ).

There are several examples of disastrous activities located in this risk area, such as the Dañana ecological disaster, the so-called BSE disease (bovine spongiform encephalopathy), the famous "Lederspray" case or the "Colza" case, not to mention yet the Chernobyl disaster and the many questions that are frighteningly asked about animal and human cloning, genetic manipulation etc. Such risks, which are produced according to a market logic, where the greater gain prevails in a faster financial return, with the lowest possible production costs, covering the largest possible number of consumers, follows production and efficiency criteria never previously experienced, which makes those risks unpredictable and uncontrollable. ${ }^{4}$

This is because, "in fact, more than a mere object of political and academic discussions, the environmental cause has become a matter of great concern of all society" 5 , from the The United Nations Conference on the Human Environment (in 1972), that has generated internal consequences for the States from the need to incorporate environmental issues in the respective Constitutions. As was the case with the 1988 Federal Constitution of Brazil, which, more than a decade later, was inspired by Principle no.

1 Ulrick Beck, Sociedade de risco: rumo a uma outra modernidade (OUP 2011).

2 BAHIA, Carolina Medeiros Bahia, Ester de Carvalho and Suélen Cristina Beninça, Sociedade de Risco, mudanças climáticas e a função reguladora do Direito Ambiental (OUP 2017) 705.

3 Beck (n 3).

4 Paulo Silva Fernandes, Globalização, Sociedade de Risco e o futuro do Direito Penal (OUP 2001) 20.

5 Felipe Santos Ribas and Arlei Costa Junior, 'A importância do compliance ambiental para as empresas: Interfaces entre governança corporativa e impactos socioambientais' (Revista Jurídica Luso-Brasileira, 2019) < http://www.cidp.pt/revistas/rjlb/2019 /3/2019_03_0581_0610.pdf> accessed 12 November 2020. 
1, of the Stockholm Declaration, to formalize an entire chapter dedicated to environmental protection, recognizing the healthy environment as a fundamental right.

It is also worth noting that, the 1988 Federal Constitution of Brazil (nicknamed as "citizen's constitution", considering that its creation process was part of a symbol of Brazil's period of re-democratization after the end of the military dictatorship $)^{6}$ was the first Brazilian constitution to mention the expression "environment" and to address the issue (and its protection), classifying it as a "good for the common use of the people" and "essential to a healthy quality of life" (according to article 225), "insofar as the quality [and the existence] of a greater legal good depends, that is, human life" 7 .

On the other hand, the 1972 Stockholm Declaration also recorded the importance of raising awareness of the social and environmental responsibilities of "by individuals, enterprises and communities in protecting and improving the environment in its full human dimension", in Principle 19.

In this way, the intensity of environmental risks caused the awakening of international society (including transnational enterprises) to the emergency in discussing new mechanisms and instruments for the defense and protection of the environment (including on command and control issues) to minimize the negative impacts when complete mitigation of environmental damage is not possible, because the degradation of the ecologically balanced environment can reach (and cause serious damage) to other places, cities, regions, countries, "causing the deterioration of environmental conditions at an unknown pace and scale" .

Take, for example, environmental disasters, emission of pollutants, oil spills, acid rain, accidents with radioactive or nuclear materials, increased Earth temperature, greenhouse effect or hole in the ozone layer, chemical waste, organic waste, among other events.

Thus, it is necessary to have a truly effective management for the protection of the environment, since it is fundamental for the construction of a sustainability model that there is an integrated management of the right to an ecologically balanced environment and of all the instruments and mechanisms made available to its adequate defense and protection, which favors cooperation (at national and international level), forming a very

6 Istoé, A constituição cidadã (2011) <https://istoe.com.br/161883_A+CONSTITUICA O+CIDADA/>. accessed on 09 December 2020.

7 Gilberto Passos de Freitas, Ilícito Penal ambiental e reparação do dano (OUP 2005) 111.

8 Édis Milaré, Direito do Ambiente (OUP 2013) 52. 
important beneficial cycle for building sustainable development, with a view to ensuring the compatibility of the socioeconomic aspect with the protection of environmental quality.

It's about perception that environmental protection has come to be considered a concrete obligation, directed towards the State's duty and law, but also imposed on individuals. That is, environmental standards must be consolidated, including by the business sector.

So, to be socioenvironmentally responsible, a enterprise has to be concerned with the management of the risks it may cause to the environment (through tools that allow planning and implementing, as well as evaluating and supervising the mapping of measures capable of minimizing or even mitigating environmental damage, avoiding any damage to society), since its actions (economic and social) can generate consequences for present and future generations, mainly in the face of disasters and impacts that have been caused to nature by the business sector (take, as an horrible example, the disasters of Brumadinho and Mariana, in Brazil).

Especially because, according to the "National Guidelines on Business and Human Rights", implemented by Decree 9.571, of 2018, in Brazil9, which influences the risk management posture of enterprises when determining that the entire business sector has an obligation to be responsible for human rights, implementing mechanisms to repair those rights that have been affected (article 2), monitoring the production chain related to the company for its adequacy to respect for human rights (article 5), among other important guidelines established in the Decree, and also, must identify "the risks of impact and the violation of human rights in the context of its operations, with the adoption of appropriate and effective prevention and control actions" (article 9), as well as "develop and permanently improve the procedures for controlling and monitoring risks, impacts and violations, and, repair the negative consequences on human rights that provoked or have contributed to provoke "(article 9, item II).

Therefore, social and environmental responsibility implies a series of benefits for the companies themselves, which will adopt a more assertive environmental adequacy process, avoiding non-compliance of sustainable standards and commitments (which, in addition, enhances the brand and

9 Decreto 9.571/2018<http://www.planalto.gov.br/ccivil_03/_ato2015-2018/2018/De creto/D9571.htm > accessed on 12 December 2020. 
adds value to the enterprise, demonstrating a more sustainable image for consumers and potential investors ${ }^{10}$ ).

It is about transforming the company into a "citizen company" (alluding to the "citizen constitution" mentioned above), with correction of socio-environmental ethical values, fulfilling its ethical and legal responsibility, in addition to being useful and profitable (in the economic sense), but also sustainable, avoiding and minimizing environmental impacts with the assumption of its productive role in society (which clearly imposes determining rules of conduct).

In other words, it is a posture and social behavior that recognizes not only the profitable importance of the enterprise itself, but also a socio-environmental responsibility, which imposes a concern for social well-being, in order to meet society's expectations about of sustainability, because "the peculiarity of the debate on the State of Environmental Law requires that reflection on the preservation of the environment cannot be restricted to isolated States only"11.

Thus, the awareness of the business sector about the importance of actions that positively impact the environment is a strategic measure for reaching global partnerships with respect to sustainable development, which can contribute significantly to the advancement of environmental protection, and, in an ultimately analysis, allows for an improvement of socio-environmental issues (mainly with regard to the mitigation and minimization of environmental disasters), but also for the achievement of the Sustainable Development Goals (SDGs), under the terms of the 2030 Agenda, of the United Nations (UN).

\section{The Contribution of Environmental Compliance to the Reach of the} Sustainable Development Goal 17

The role played by the private sector is extremely important for the due achievement of the SDGs, of the 2030 Agenda, formulated by the UN, mainly with regard to SDG 17 , which is entirely connected to the conduct of positive behaviors (as is the case, for compliance).

10 José Carlos Barbieri and Jorge Emanuel Reis Cajazeira, Responsabilidade social e empresarial e empresa sustentável (OUP 2010) 03.

11 José Rubens Morato Leite, 'Sociedade de risco e estado' in José Canotilho and José Rubens Morato Leite (eds), Direito constitucional ambiental brasileiro (OUP 2015) 179. 
The 2030 Agenda has the proposal of reflecting the new challenges of the current globalization and the Risk Society ${ }^{12}$, with the final purpose of achieving the dignity of the human person (in all its aspects, including environmental), by providing programs, actions and guidelines, also with a view to sustainability, on a new standard of development, by reconciling environmental protection with social justice and economic efficiency.

To this end, world leaders adopted the SDGs (through UN General Assembly Resolution $70 /{ }^{13}$, with the title "Transforming our world: the 2030 Agenda for Sustainable Development") ${ }^{14}$, at the UN Summit, from 25 to 27 September of 2015, with the purpose of succeeding the Millennium Development Goals (MDGs), of the former Agenda 21, signing, thus, a new and current commitment among all UN members that proposes to provide programs, actions and guidelines for an ambitious development Agenda by 2030 , aiming at strengthening consensus among signatory countries on environmental cooperation.

Thus, the new Sustainable Development Agenda calls for poverty eradication, environmental protection, gender equality, disease prevention, universal education, inclusive economic growth and good governance, through 17 SDGs (subdivided into 169 targets, which now include social, economic and environmental aspects with the indispensable application of public policies aimed at such areas, for the creation of a healthy relationship between society and the environment), acting as a means of guiding actions and international cooperation by next 15 years.

Each of the 17 Goals has a specific content, therefore, its own purposes. The demand is so high that the UN involves all actors in its development, governments, the private sector, civil society and individuals. This leads to collaborative strategies to achieve sustainability and the improvement of life for future generations. ${ }^{15}$

Therefore, it is true that the document includes, for the first time in an international agreement of this type, a commitment to the need for new mechanisms to implement the goals brought about by the SDGs.

12 Beck (n 3).

13 Assembleia Geral da Organização das Nações Unidas, Transformar nuestro mundo: la Agenda 2030 para el Desarrollo Sostenible (A/70/L.1, 2015)<https://unctad.org/m eetings/es/SessionalDocuments/ares70d1_es.pdf> accessed on 21 December 2020.

14 Organização das Nações Unidas, Agenda 2030 (OUP 2015) <https://nacoesunidas. org/pos2015> accessed on 10 December 2020.

15 José Júlio Rodriguez, ODS 16: paz, justicia e instituciones flertes (OUP 2018) <http://www.ieee.es/Galerias/fichero/docs_investig/2018/DIEEEINV18-2018O DS.pdf $>$ Accessed on 09 December 2020. 
Among such Goal is the 17, which has as its guideline "Partnerships and Means of Implementation: Strengthen the means of implementation and revitalize the global partnership for sustainable development", especially with regard to the specific goals of no. 17.14, 17.16 and $17.17^{16}$.

It is, in fact, an axis of SDG 17 focused on systemic issues thought of mechanisms of "institutional policy sciences" (which seeks joint and stable efforts), "multisectoral partnerships" (in which there is a search for partnerships of the Public authorities with non-state actors and civil society to mobilize and share knowledge, expertise, resources and technologies) and "data, monitoring and accountability" (through the training of developing countries, to increase the availability of high quality data, which are reliable, according to their national contexts on the implementation of the goals of the other SDGs).

This is because cooperation between the international community, interested sectors and people affected by development processes is an essential requirement for growth on new sustainable standards.

Thus, SDG 17 is the path to the effective realization of all other SDGs in the 2030 Agenda, in a true coordination of national and international efforts, which requires the participation of all, including companies (by allowing expanded participation as a vital mechanism for good governance, in the new terms of non-state actors and subjects of Public International Law).

Currently, one of the biggest mechanisms that make such a commitment possible on the part of enterprises is the so-called compliance, which refers to acting with pre-stipulated internal rules, such as a command or corporate norms.

By the definition of article 7, item VIII, of Law no. 12.846/2013 (which provides "about administrative and civil liability of legal entities for the practice of acts against public administration, national or foreign" ${ }^{17}$, and also programs "are internal mechanisms and procedures integrity, auditing, incentive to report irregularities and the effective application of codes of ethics and conduct within the scope of the legal entity"18, with the applicable rules (including environmental) to the business sector in question (whether standards are imposed or voluntarily adhered to).

16 Organização das Nações Unidas, Parcerias e meios de implementação (OUP 2015) $<$ http://www.agenda2030.org.br/ods/17/> Accessed on 05 December 2020.

17 Lei 12.846/2013. > http://www.planalto.gov.br/ccivil_03/_ato2011-2014/2013/lei/11 2846.htm> Accessed on 14 December 2020.

18 Ribas and Costa Junior (n 7) 14. 
In other words, it is the set of actions and internal activities carried out by companies that allow a true mapping of positive behaviors, in order to prevent and/or minimize the risk of violations of environmental standards, as well as to monitor and inspect the implementation progress of such actions and activities in order to avoid environmental damage, for example, by sharing information and promoting transparency actions in order to avoid lawsuits, imposing penalties and any consequences harmful to society.

It is an imperative of conduct which imposes control (through monitoring and inspection) of the attitudes taken by the enterprises in order to obtain environmentally appropriate behaviors, in accordance with pre-established ethical and moral principles (including 2030 Agenda), effective both for the public and private sectors, a true prevention and precaution mechanism within organizations.

Thus, environmental compliance aims to avoid irregularities or violation of any standards that may cause damage and/or disasters (often irreparable to the population), through the effective implementation of environmentally appropriate strategies to enhance compliance with standards, transparency and implementation of measures preventive and precautionary measures, in addition to internal environmental education training for partners and employees (which, in turn, generates the production of a cycle of positive behaviors, based on strengthening the building of environmental education). And, ultimately, it allows the maintenance of the enterprise's positive image towards society (and possible consumers).

However, the creation of this scenario is only possible through the opening of constructive, inclusive and resilient communication channels, what is possible to be done through social and environmental mediation mechanisms.

\subsection{Mediation as an instrument of compliance and prevention of environmental disasters: Negotiated conflict resolution strategy for environmental risk management, through governance}

It is clear, therefore, that the pursuit of social responsibility from the perspective of sustainability requires concrete attitudes that enable environmental protection promoted by intense debate and, later, consensus on the issues.

That is why, as mechanisms for implementing compliance (which aims to map risks for a preventive and precautionary consensual action), governance should be used through its socio-environmental mediation 
instrument, which presents itself as an important tool for environmental and business policy, effective in protecting the ecologically balanced environment, and which adds value to enterprises.

Governance has become a common expression, since the beginning of the 21st century, in the areas of Humanities, Applied and related Social Sciences, as being essential for the processes of economic and social development, since it covers several areas, such as, for example, political, technological, cultural, among others, as it is the "set of interrelated processes that operate through all the primary fields of social power" 19 .

The current concept of "Global Governance" emerged through the Commission on Global Governance, by the United Nations (UN) in 1992 (with an official report in 1994), as the totality of the different ways in which individuals and public and private institutions manage their common problems. It is an ongoing process by which it is possible to accommodate conflicting interests and carry out cooperative actions. Governance concerns not only institutions and formal regimes authorized to impose obedience, but informal agreements that serve the interests of people and institutions ${ }^{20}$.

It is, therefore, considered a solution to common problems between States and non-State actors with the intention of formulating principles and guiding actions and activities that allow the designation of capacities required for an adequate and sustainable management of the environment, "adopting stricter social and environmental policies, and, guaranteeing a more active role for citizens and local agents" 21 , bearing in mind that there is an increasing concern to establish forms and mechanisms of shared power management in a transparent manner, where States, international organizations, multinational companies and civil society organizations can play a relevant role.

Thus, in order for an integrated solution to common problems to be possible, it is necessary to create new formulas, which enable the expansion of participation in all phases of the decision-making procedure (discussion, execution, monitoring, inspection etc.).

With regard to an action-oriented approach, authors have characterized governance as a multi-actor system which extends beyond traditional actors (such as states and international organizations) and includes non-go-

19 David Held and Anthony McGrew, Prós e Contras da Globalização (OUP 2001) 18.

20 Comissão sobre Governança Global, Nossa comunidade global (OUP 1996) 2.

21 Alcindo Gonçalves, "Governança Global e o Direito Internacional Público" in Liliana Lyra Jubilut (eds), Direito Internacional Atual (OUP 2014) 84. 
vernamental organizations, in particular, activist groups, networks of scientist, business associations and policy research institutions. While states, at least formally, are still the primary actors within this framework, there is a growing number of non-governmental organizations (NGOs), societal movements and other private actors which are transforming the character of the whole system. (...) Last but not least, the individual has become increasingly involved as an actor. ${ }^{22}$

Thus, "governance is a means, tool, instrument for solving problems"23, designed to encompass new decentralized relationships, seeking to go beyond of simply solving problems, to also encompass much broader discussions with States, civil society and the business sector.

However, for this phenomenon to be properly employed, it is necessary to build mechanisms for participation and dialogue in the search for consensus in decision-making and environmental management through joint procedures for diagnosis and, from there, building the solution and subsequent implementation and monitoring, that is, in the search for a final result after processes of discussion and interaction between all those involved in that problem (instead of coercion and imposition).

The consensus is present "when it is able to articulate the different actors - State and non-State - to face challenges acting and articulating from the construction of consensus and forging cooperation to solve problems" 24 , considering that it must be understood as the search for viable solutions and accepted by the majority, after the discussion between all involved.

It refers, therefore, to activities that support common goals, which may or may not derive from legal and formal prescriptions, but which, due to its intrinsic condition, should be accepted and/or supported by the majority.

This new relationship of management and discussion of common problems, based on constructive and respectful interaction, can be implemented through socioenvironmental mediation, because if governance is oriented towards the search for consensus, it can be translated (and implemented) by mediation of different interests, being one of the main governance

22 Ulrich Beyerlin and Thilo Marauhn, International Enviromental Governance. (OUP 2011) 244.

23 Alcindo Gonçalves and José Augusto Fontoura Costa, "Governança Ambiental Global: possibilidades e limites" in Maria Luiza Machado Granziera and Fernando Cardozo Fernandes Rei (eds), Direito Ambiental Internacional: Avanços e retrocessos (OUP 2015) 109.

24 ibid 25. 
instruments when providing precisely the expanded participation in the decision-making processes, since several actors play decisive roles in the resolution of conflicts of interest.

In this way, mediation allows the negotiated solution process, in order to facilitate the approach of the parties involved (through their active participation) so that they find, in a consensual way, through stimuli from a third party (who only has powers to assist the conflicting interests in the construction of the solution), a satisfactory result that will be built throughout the process.

The Law no. 13.140/2015, which constitutes a true legal framework on the subject, dispose of mediation as a means of dispute settlement, considers the concept of this instrument to be (according to article 1): "Mediation is considered to be the technical activity performed by impartial third party without decision-making power, which, chosen or accepted by the parties, assists and encourages them to identify or develop consensual solutions to the controversy" 25 .

In other words, through mediation as an instrument of governance, it is possible to improve the relationships between those involved (thus allowing the broadened participation of all stakeholders), through dialogue, to move forward in building cooperation between the parties to find consensus on a more appropriate solution for all, in a dynamically way by empowering the actors involved in decision-making and execution of business management, providing satisfaction and security to the parties, in addition to reestablishing personal relationships.

It can be seen that mediation plays an important role in combining the interests of everyone involved in the enterprise: investors, partners, shareholders, banks, employees, consumers, among others, through the opening of constructive communication channels, inclusive, resilient and, why not, now facing the 2030 Agenda, also sustainable.

Therefore, it is an important mediation process for the management of environmental and business interests "between social actors who act on the physical-natural and built environment, aiming to guarantee the right to an ecologically balanced environment, as determined by the Brazilian Federal Constitution"26.

Thus, compliance, as a mechanism of responsibility, integrity and risk management, depends on the proper performance of socio-environmental

25 Lei 13.0140/2015 < http://www.planalto.gov.br/ccivil_03/_ato2015-2018/2015/lei/l 13140.htm > accessed on 16 December 2020.

26 José Silva Quintas, Introdução à gestão ambiental pública (OUP 2006) 30. 
mediation (as a mechanism for strategic management of environmental, economic and social interests) for its effectiveness.

In other words, mediation, as a compliance instrument, can be used for issues involving socioenvironmental conflicts in the search for negotiated solutions among all interested and involved actors, aiming at the protection of environmental quality, under the terms of the 1988 Brazilian Federal Constitution, according to article 225, to ensure an ecologically balanced environment for all.

An example of this possibility of applying governance and socio-environmental mediation is the online platform called "SDG Action Manager", created by B.Lab and the United Nations Global Compact ${ }^{27}$, which has the purpose to assist enterprises in determining better and more positive actions for the environment, directing them within the reach of the SDGs, of the 2030 Agenda, with the adoption of significant measures for this, and, of course, ultimately, social welfare. It is a free and confidential tool for the impact of risk and socioenvironmental management (by allowing the measurement of socioenvironmental impact, defining objectives for the improvement of concrete actions), and it is capable of actively contributing to the combination of interests in the business sector, with the union of efforts towards a common goal: to improve the business performance related to sustainable development for all, rethinking models and promoting sustainable collective actions.

To this end, the platform works by studying the alignment of strategies and operations (already implemented and/or still in delimitation, but which, in any case, are registered on the website) of enterprises with the SDGs. When analyzing the information provided (with the support of experts in business sustainability, including the UN and the scientific community), the site indicates risks, business opportunities and current trends for that particular sector (all in accordance with the SDGs, provide what the objetive of each Goal are most important according to the enterprise's performance profile), in addition to proposing objetives (of high impact) that can serve as the basis for an action plan in order to become more sustainable by encouraging a corporate action and self-assessment, that is, a proposal for reform in performance so that activities and environmental management are in line with the search for adaptation to new global scenarios and the demands of society of sustainability. In the end, it is

27 Global Pact, Sdg Action Manager (OUP 2020) <https://www.pactoglobal.org.br/pg/ sdg-action-manager $>$ accessed on 01 December 2020. 
also possible to share the results obtained, in order to generate even more positive impact on the enterprise.

It is a platform (which requires a simple registration, made free of charge and completely confidential) that gives companies an opportunity to "learn, manage and directly improve their performance" 28 , according to the SDGs of 2030 Agenda, which is umbilically connected to issues of governance and socioenvironmental mediation (by allowing everyone to participate and discussions together).

\section{Conclusions}

Sustainable development seeks to combine quantitative and qualitative factors in the search for social integration and economic growth, in addition to preserving the environment so that present and future generations can enjoy quality of life.

This is because, the environmentally harmful effects of the risks produced by the current society are enormous and incalculable, since it doesn't respect borders and reach several generations (in a true sense of transnational and intergenerational). A long-term relationship of social and legal responsibility arises to define actions in favor of the environmental quality, life and dignity of the human person, by all members of international society, whether it be a classic subject of Public International Law (such as States and International Organizations), an non-State actor, as is the case with transnational companies (alongside others, for example, academic institutions, non-governmental organizations, individuals, among others).

This is because, governments alone are no longer able to achieve the SDGs of 2030 Agenda in a current Risk Society. Joint and effective action by other public and private actors is necessary in order to make sustainable development feasible.

Because of this, it is extremely important to understand and practice concrete, effective and strategic actions to reach the SDGs of 2030 Agenda, by the signatories of this global pact, demonstrating the responsibility for the dignity (including environmental) of future generations, which brings benefits to the international society, but also, in the long term, to the enterprises themselves (improving its image, and adding value), which start promoting social welfare with financial balance. 
This involves, for example, the use of the tool known as compliance (which seeks to map risks in order to minimize with action plans and internal policies in the prevention and precaution of environmental risks), with pre-defined objectives that need consensus and constructive dialogue for its implementation.

This reality can be implemented through mechanisms provided by socioenvironmental mediation, which allows the participation of all those interested in the discussions, in order to make it effectively inclusive, resilient and sustainable, helping to guide more positive behaviors in relation to the environment, implementing SDG 17, of 2030 Agenda, through partnerships for sustainability. 
